\title{
The conceptualised role of African diaspora in the renaissance of the African continent
}

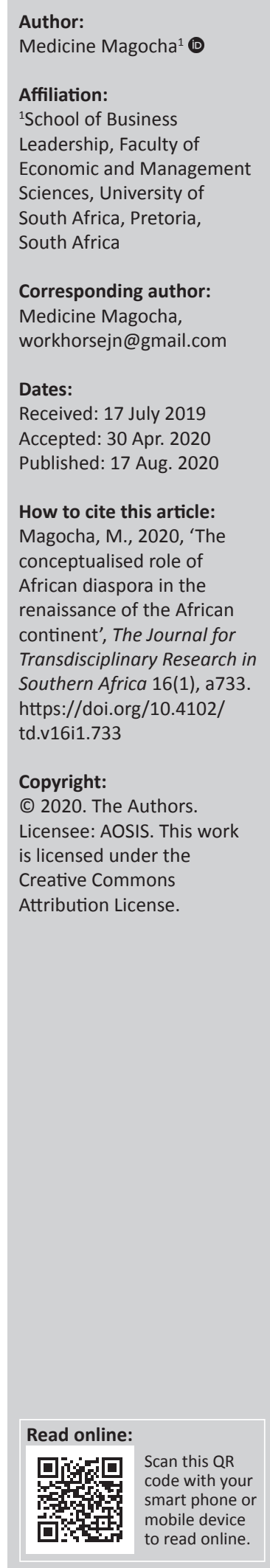

The concept of diaspora is phenomena. However, it is discussed conservatively by scholars in the fields of economics, spatial geography, politics, development studies, sociology and social anthropology. This article discusses the African diaspora as a tool for fostering the African renaissance. Most, if not all, African countries were once colonies of Western states, which imply that both people and economies were deprived of freedom of movement and freedom of association both within Africa and beyond. They were therefore recipients of the so-called renaissance of the colonial masters, who were themselves diasporas of their mother nations. In fact, the Western states themselves obtained some form of renaissance from Africa, although they allegedly propose themselves to be the torchbearers of the African renaissance. The term 'renaissance' refers to an endless process of systematic transformation, systematic change and systematic reformation and is thought to be contagious. Accordingly, the African diaspora is contributing to an African renaissance in all domains of life, that is, economically, socially, politically and technologically. Those who have left Africa are facing what this article would refer to as 'payback time' - repatriating resources to the African continent in order to pay back. The diaspora is thus playing a distributive role, transferring resources from regions of higher concentration to regions of lower concentration through 'impermeable membranes' (country borders) that are never porous. This article seeks to conceptualise the role of the African diaspora, examining and/or defining who forms part of the diaspora, by outlining the challenges of such a role in the continent. The respective governments of the country in which the member of the diaspora is now residing and the government of the homeland in Africa should be involved in the way forward towards facilitating the contribution of the diaspora in terms of the revival of Africans' humanity and Afrikology. Moreover, they should be pushing for the creation of a United States of Africa.

Keywords: diaspora; renaissance; systematic reformation; border jumper; alien; migration; transnationalism.

'We must redouble our efforts to involve the diaspora and the migrants in the development process in order to widen our constituency, gain more support and increase our knowledge about development.' (Agnes van Ardenne, Minister for Development, the Netherlands, speaking in January 2003 to the National Community Development Organization[NCDO]).

\section{Introduction}

The concept diaspora is dynamic in nature and it is studied from a wide range of perspectives. Geographically, diaspora is studied from within the African continent looking at Africans moving from their home countries to other African countries or is studied from external boundaries. Historically, the issues pertaining to the history of migration are included in this discussion. A diaspora can be defined as people who have migrated and their descendants who maintain a connection with their homeland. The issue of migration has taken centre stage in African economics, politics and sociology. Some proponents argue that migration destructs the existing systems of a host country; on the other hand, supporters of migration purport that it is a fundamental element of the world system. Globalisation facilitates movement across various regions (through regional integration) (Ellerman 2003) and is thus a major topic in the 21st century, posing social, economic and political challenges for policy-makers in the future management of migration for the betterment of African societies.

Makina (2009) proposes that free trade economics treats labour, goods and capital as the factors of production that should be allowed to move freely to maximise welfare gains on both personal and global levels. International borders and constraints on migration tend to be treated as market failures. Cross-border migration refers to migration between states that share a common border. 
This has generated a number of offensive terms directed at immigrant groups, dubbing them 'border jumpers', 'illegal immigrants' and 'illegal aliens' amongst others (McDonald et al. 1998). Cross-border migration remains a controversial issue especially in government circles. In South Africa, crossborder migration takes various forms and is both formalised and non-formalised. Crush (2000:13) observed that whilst there is a highly formalised and regulated contract system in relation to the mines and farms, there is also informal, unregulated or clandestine movements across borders.

From a closer scrutiny of the issue pertaining to the African diaspora and the renaissance of the African continent, one may perceive that the role of the diaspora in African renaissance is a highly contested terrain. If the diaspora is not treated with the respect it deserves, it may result in an uproar amongst politicians and economists, social commentators and neoliberalists.

The following news headlines from various broadcast media highlight both a pessimistic and an optimistic historical view of Africa:

Hundreds of illegal immigrants on hunger strike in Zambian jails. (Melvis Dzisah, Deutsche Presse-Agentur, 26 September 1998)

Immigration law draws criticism from neighbors. (Panafrican News Agency, 22 September 1998)

South Africa: Immigrants are creating work - not taking our jobs. (Chiara Carder and Ferial Haffajee, Africa News, 11 September 1998)

Southern Africa: SADC protocol stirs hornet's nest. (Tabby Moyo, Africa News, 11 September 1998)

African leadership is ambivalent on the issue of migration and its contribution to the betterment of humanity. Zimbabwean leaders, for example, late president cde R.G. Mugabe, pessimistically believed that migration cannot give birth to an African renaissance; hence, they allowed issues likexenophobia to go unchallenged especially during the Zimbabwean land grabbing of the 2000s. However, some leaders like those in South Africa, for example, former President T. Mbeki, are optimistic when it comes to a renaissance.

\section{Methodology}

The research methodology applied in this study is critical discourse analysis (CDA). it is agreed upon that any explicit method in discourse studies, the humanities and social sciences may be used in CDA research, as long as it is able to adequately and relevantly produce insights into the way discourse reproduces (or resists) social and political inequality, power abuse or domination. This method was used because it does not limit its analysis to specific structures of text or talk, but systematically relates these to structures of the sociopolitical context. Critical discourse analysis has been used to examine political speech acts, to highlight the rhetoric behind these, and any forms of speech that may be used to manipulate the impression given to the audience.

\section{Migration and renaissance: The double-edged catalysts of humanity's evolutionary continuum}

There have been many black or African or Africoid renaissances since the earliest period of human history and culture. Homosapiens in the form of medium to tall, dark-skinned, smooth-skinned (no body hair), cloth-wearing (other materials) people existed as early as 40000 BC (Choi 2014). However, fully human people migrated from Africa as early as $100000 \mathrm{BC}$. In addition, an advanced culture also migrated from Africa about $60 \quad 000-50 \quad 000$ BC (Grenville 1997). One group migrated to various parts of Africa, particularly the Sahara and West Africa, in countries stretching from around Sudan, Somalia and Eritria to mention just a few. Another group migrated to southern Europe and the Middle East (Grimaldi Negroids), while another went to India. Many migrated to the southern regions of East Asia and to Australia and Melanesia (Barton 2001). The group that migrated to India comprised completely black Negroids from the eastern part of Africa. In fact, people from Africa were resident in India 70000 BC, and many people in India today (at least 600 million), who have Africoid features, curly to straight hair and brown to black skin, are, in fact, related to African black people and are called IndoNegroids (Zlotnik 1998). These particular groups of Africoids were the first people to move into Europe after the Ice Age began to diminish and Europe's ice sheets began to melt about 20000 years ago. The black people of India, who originally migrated from Africa, continued to migrate into Central Asia and then Europe from the Indian subcontinent. However, before the Indian black people moved into Europe, an earlier group of Africans moved into Spain, Armenia, Russia and Europe from the Egypt-Arabia region. In addition, many sailed along the coastline all the way to Melanesia and Australia, beginning with the Negritos and then the taller black people similar in appearance to East Africans and South Indians. A very ancient group of Africoids arrived in Brazil about 30000 BC according to Brazilian scientists, who have found Negroid skulls in the north-eastern part of Brazil (Tannenbaum 1946).

This humanity's evolutionary continuum history includes many African or black renaissances in Africa, the Americas, Europe, East Asia and India. These renaissances, which have taken place since $20000 \mathrm{BC}$, include the first renaissance that took place in prehistoric Sahara, the Zingh Empire, which was the world's earliest culture and civilisation. Unfortunately, the term 'Zingh' is known by very few people today and is often used as a pejorative term by some Middle Eastern people to refer to black or African people. Similarly, the term 'Kushim', which originates from the great Kushite civilisation, is used by people of Middle Eastern origins to refer to black people. Cultural inventions such as mummification, red or black pottery, governance, education, fishing nets, the boomerang, the bow and arrow, clothing, boats and many cultural artefacts found as far afield as New Guinea, China and the Americas emerged from the prehistoric Zingh Empire and were spread by the diaspora mobility (Jefferson 1944:355-362) 
From the above discussion, it can be noted that migration played a pivotal role in the dispersion and mixing of people in previously unoccupied regions of the world. Some schools of thought, for example, Mbeki (1998), Mbeki (1999), Makgoba (1999) and Hammar, McGregor and Landau (2010), argue that there is widespread hope that two factors might produce an African renaissance in the 21st century: (1) changed external circumstances, such as an end to the Cold War and its proxy conflicts in Africa; and (2) changes in Africa, including the emergence of democracy in many countries, the market penetration in and out of Africa and a new generation of leaders who must justify their power on the basis of what they can do for their people rather than their role in winning independence. African Union (AU) and Southern African Development Community (SADC) support movement of people and products within and outside Africa.

\section{The diaspora and the renaissance function}

The global diaspora relates to the study of migration, although the term 'diaspora' technically serves as an umbrella term that covers all types of migration. Interest in the link between diaspora and transnational migration has grown significantly in recent years, and more studies on globalisation, global economics, international relations, global politics, international conflict resolution and foreign diplomacy have been produced (Campagnon 2011). The design of transnational migration is not new; however, its influence and form have expanded dramatically over the years. Levitt (2001) notes:

The assumption that people will live their lives in one place, according to one set of national and cultural norms, in countries with impermeable national borders, no longer holds. Rather, in the 21st century, more and more people will belong to two or more societies at the same time. (p. 4)

This diaspora and renaissance function is possible because of advanced technologies in modern transportation and communications. Castles (2010:44) explains that 'some people develop a transnational consciousness, and maintain economic, cultural and social relationships in several places'. Blakewell (2010) echoes Levitt's (2001) assertion by connecting the diaspora peoples with migrants and transnationals. Accordingly, diaspora becomes a 'social form' that emphasises 'an identified group characterised by their relationship-despite-dispersal'. He says that the 'set transnationals do not necessarily consist exclusively of migrants and many migrants may not maintain transnational activities'. Blakewell (2010) perceives diaspora 'as a subset of transnationals, and both the sets of transnationals and diasporas intersect with the set of migrants'. Defining diasporas by their 'transnational character', he asserts that the term 'diaspora' can be 'reserved for particular people living in distinctive relationships with each other and a homeland'. Indeed, according Blakewell (2010:3-4):

Not all migrants become diasporas and not all diasporas can be considered as migrants (although their ancestors may have been so). Likewise, not all those who engage in transnational practices are necessarily diasporic; they may simply be operating as networks of people with limited relationships to any place (real or imaginary).

Echoing Blakewell's point, Levitt (2010:5) proposes:

... [M]oreover, not all migrants are transnational migrants, and not all who take part in transnational practices do so all the time ... Most migrants are occasional transnational activists. At some stages in their lives [,] they are more focused on their countries of origin while at others they are more involved in their countries of reception. Similarly, they climb two different social ladders, moving up, remaining steady, or experiencing downward mobility, in various combinations, with respect to both sites.

Broadly speaking, diaspora refers to the global phenomenon of the dispersion or scattering of people in various parts of the world, occurring either by a voluntary act or coerced conditions in both domestic and global contexts. Migration facilitates geographical or demographic mobility that eventually results in diasporic conditions. Migration basically involves geographic and demographic flows of people or individuals, taking both internal and international directions. It is important to view the inherent connection between diaspora and migration because of their symbiotic relationship. Iroegbu (2010:1) argues that:

\begin{abstract}
... [M]igration or diasporism is substantially a human capital issue involving an individual or group. It is also structural in terms of forces that push people around for safety and income as the dual market theory suggests. That is, people move with the hope to be better off than they were before. Staying at home maintains their current living conditions, where chances of progress are more likely in another place. However, moving brings about a change, a change hoped to be better - therefore security, empowerment, and opportunities will be filled with choices.
\end{abstract}

However, whilst both are complementary, they are not identical or interchangeable.

Iroegbu (2010:1) insightfully remarks:

Diasporism makes sense because it may forge stronger ties between the homeland and outside individuals. Diaspora communities show that diaspora issues are an important category to initiate and seek out ideas and accommodation of ways and forms in which intercultural and international relations between homeland and settled ethnic nationalities can strengthen one another. As a fact, it can help in sustaining new democratic nation states with the flow of ideas and social obligations in agreement with the home-inward and the home-outward. The meaning of diaspora therefore resonates with, but is not limited to, the connection and feeling of asking those in diaspora how and when they would go back home and be relevant.

\section{Diaspora in theological and cultural contexts and the resultant renaissance}

Five major theological considerations can be stated in this theological and cultural context resulting in African renaissance. Firstly, the global diaspora phenomenon situates 
Adam and Eve in the Garden of Eden and their eventual departure from their 'original homeland'. Disobedience caused this permanent departure and catapulted Adam and Eve to the apex of irreversible exilic migration. In this sense, the diaspora may be perceived as a form of divine retribution. Wan and Tira (2008) sombrely note that 'Adam and Eve's expulsion from the Garden because of $\sin$ is the first recorded involuntary migration'. Secondly, the breadth of global diaspora links historically to extreme Jewish nationalism. With Israel's perennial exclusivist tendency as the backdrop, the Jewish diaspora may be construed as a form of hermeneutical corrective to check nationalistic particularism. They thought Yahweh was 'located' with them, but not with other nations outside their borders. Yahweh's redemptive plan for all nations was supplanted by the Jews who stubbornly localised his presence within the boundaries of Israel and Judah.

Thirdly, the global diaspora phenomenon accentuates the reality of divine justice. In this strict sense, the dispersal of the Jews in particular and the scattering of people in general may be interpreted as a form of divine judgement. People were scattered in many places, going in many directions after the confusion of languages at the Tower of Babel. Nevertheless, the exilic presence of the Jews in an environment of dispersion paved the way for cross-cultural engagement, multiculturalism in the host country and, eventually, cultural transformation.

Fourthly, the global diaspora phenomenon signifies the grand redemptive plan of God for all nations. Here, diaspora functions as a form of divine strategy to fulfil the universal missionary mandate. Again, God's sovereignty encompasses the scattering of people from various quarters of the world for an expressed missionary intention. Doors of opportunities for evangelism open up as people move. Given the emerging realities of transnational migration, people in dispersion can have direct access to the gospel without losing their ethnic identity (Lewis 2005:673-675).

Finally, according to Zaretsky (2006), global diaspora is a central theological frame for interpreting God's redemptive acts in the world based on the triune God's revelatory nature. The diaspora 'has shaped Jewish identity and history'. In a similar vein, if Christian identity and history can be viewed as diasporic, then the rest of human identity and history could follow. In other words, diasporas cannot be monopolised by the Jews or Christians because the rest of humanity also belongs to global diaspora communities. To state precisely, global diaspora is best construed as a 'theological form' that accentuates God's missionary intention for people on the move and the redemptive acts that go along with it, both domestically and globally. However, Wettstein (2002:47-59) considers diaspora as a political idea that suggests a geopolitical dispersion. Wettstein perceives diaspora as a business movement instead of a theological position: the diasporas started colonising Africa. According to Wan and Tira (2008:44), evidently, all efforts to define diaspora missiology point to the fact that the global diaspora phenomenon both embraces and transcends sociology, demographics, law, economics, anthropology, migration and labour. Global diaspora missiology integrates many related disciplines on how God'smission is accomplished through the diaspora peoples.

With this movement of theological and cultural message as the word was being spreaded by missionaries, the concepts of African renaissance were also being imparted in the communities. Missionary diaspora came with the establishment of many schools, hospitals and churches. Theological and cultural movements also improved people's morality and identity.

\section{Diaspora in Afrikological contexts and the resultant renaissance}

In Africa, diaspora movements have existed since the great trek of the likes of Nyatsimba Mutota, who moved from Great Zimbabwe to the north in search of salt reserves, and Lobengula and the great exodus from South Africa to Matabeleland in Zimbabwe (Beach 1994). These movements were later modified by colonialisation by the British, who had a wrong perception of Africa; they considered Africa to be the 'dark continent'. Therefore, they considered their portioning up of Africa to be a blessing. A case in point is the discovery of things even when there were already people there. For example, David Livingstone is said to be the one who discovered the Victoria Falls. The question which then comes in mind is, how can one be attributed with the discovery of a place which was already occupied by Africans before the person arrived? According to the Oxford English Dictionary, 'discovering' is defined as finding the existence of something for the first time.

Ratha and Mohapatra (2011) argued that diasporas are one of the contemporary global forces shaping directions and trends in the 21st-century African renaissance. This makes it important to partner and join forces with them in the development efforts in their respective homelands. Accordingly, policy seminars have been organised to contribute to the ongoing policy dialogue on migration and development from the perspective of the diaspora - a point of view that has not been sufficiently heard. The objective is to stimulate the active participation of the diaspora in the dialogue and in the generation of ideas and policy insights so as to make their critical voices count in discussions related to migration and development matters at different policy levels (Mohamoud 2008:4). This constitutes the renaissance part of Africa by Africans themselves, not by external forces. Diasporas are the most important strategic stakeholders in the migration and development field and it is therefore essential that they should be involved in policy discussions, because the practical implementation of any policy proposal requires migrants to play a leading role in the process. More importantly, migrants are the chief agents in the establishment of linkages between migration and 
development, and without their strategic interventions, it is unikely that initiatives on development and migration can succeed or achieve the expected results. This reality makes it impossible to design appropriate policy instruments without tapping creatively into the input and intellectual resources of the diasporas, whose wealth of knowledge and practical experiences are largely undercapitalised.

The contemporary African diaspora from the continent now living in the European Union (EU) countries alone is estimated to be around 3.3 million people of whom 1 million is from sub-Saharan Africa (United Nations Population Division 2002). Currently, it is around 8.7 million in North Africa and around 21.8 million in sub-Saharan Africa (Ratha \& Mohapatra 2011). The numbers of the African diaspora would probably be high if they are added to those living in other countries in Europe. In this regard, the diaspora is the greatest offshore asset of Africa because of the potential of its considerable human and financial capital that needs to be exploited for the benefit of Africa. The African diaspora now occupies an indispensable strategic position that links the developed North with Africa in a more connected manner. For example, the African diaspora is now in a unique strategic position in this ever-globalising world as it is scattered in different economic and power centres around the globe. The huge presence of the African diaspora in powerful political centres, such as London, Paris, New York and Washington, where global policy decisions are made, has an especially important strategic significance. Yet, in comparison with Asia, Africa has not taken full advantage of the vast untapped potential of its diaspora overseas.

The activities of the African diaspora promote trade and enterprise links and other social and political ties between their adopted countries and their countries of origin. This is why diaspora-initiated projects are now referred to as the 'fourth development aid' (Mohamoud 2008) after international organisations, governments and mainstream development organisations. In Zimbabwe, the diaspora sustained the economy for more than 10 years and organisations like Homelink-Kumusha-Ekhaya were established to harness this bounty from Zimbabwean nationals abroad. Mohan and Zack-Williams (2002:211-236) assert that the African diaspora frequently adopts ingenious strategies to maximise the advantages that the contemporary globalisation process has presented them. For example, the African diaspora, like others elsewhere, forges innovative patterns of 'globalisation from below' in which individual and group players, rather than mega-corporations, benefit from and make use of the opportunities offered by globalisation. A number of African diasporas in the West are realising that they are obliged to contribute towards the rejuvenation of their continent in terms of politics, socialisation and economic status. They hold the view that this strategic position enables them to channel information, innovative ideas, intellectual capacities, new technological skills, smart and innovative business and trade practices, peace-making tools and techniques and democratic political habits and practices from the West to Africa. Mohamoud (2003) highlights:

Egypt considers its diaspora as its treasures kept abroad. It is vital to affirm that these unclaimed treasures can potentially serve as another window to the industrialised world, as another bridge in knowledge transmission and exchange, and as another catalyst in fostering knowledge creation and utilisation. It is apt to remark, therefore, that the diaspora is a vital and influential community of 'undercover' ambassadors - of their home countries and regions - without a formally designated portfolio.

Actors in diaspora networks can be crucial bridges between global state of the art in policy, technological and managerial expertise and local conditions in their home countries. Public sector reform, innovations in education and social services and promotion of a knowledge-based private sector are just a few areas where diaspora members could team up with developing countries' governments and external funding agencies to promote a shared agenda of poverty reduction.

The success of the Chinese diaspora grew out of - although it is no longer limited to - the traditional investment behaviour of emigrant families that made their fortunes overseas. On the other hand, the success of the Indian diaspora is much more closely linked to recent changes in supply chain organisation and the emergence of transnational innovation networks than to the investments of fixed capital of Indian diaspora members in India. Although a decade ago the success of the Armenian diaspora seemed nearly certain, it has failed to contribute substantially to domestic development (at least relative to its potential). The political divisions between the diaspora and the post-Soviet political class in Armenia, combined with the philanthropic generosity of overseas Armenians, thwarted development and buffered domestic actors from the costs of their actions (World Bank 2005). This kind of diasporic trend is appearing in African diaspora activity, which is why Africa is failing to benefit from the diasporic treasures. Africa's hope is that diaspora networks can overcome obstacles to in-depth integration by serving as an entry point into new markets. Diaspora networks mesh so well with the architecture of the modern knowledge society that they are coming to be seen as one of its natural building blocks. Studying diaspora networks helps uncover the partial solutions that are working. It helps formalise the networks, rendering them more effective as incubators for new programmes and as governance structures for new projects. It also reveals potential win-win dynamics benefiting both sending and receiving countries.

\section{Diaspora and the South African renaissance in the 21st century}

At the beginning of the 21st century, it was possible to claim that 'Africa and the African diaspora stand fused in ways that have immense political, economic, and social possibilities for the new millennium' (Akyeampong 2000:214). Despite the perception that emigration is dominated by skilled white South Africans, research has shown that there is no difference 
across racial groups in the desire to emigrate. Skilled South Africans began emigrating in large numbers before the end of apartheid and the turn to democracy in 1994. The data do not permit an accurate estimate of the skills lost, as the South African Department of Home Affairs and Statistics of South Africa takes into account only emigrants who report themselves as such. The actual number of emigrants could be as much as three times the official figures. Nonetheless, it is widely agreed that skilled workers continue to leave South Africa. About two-thirds of workers with the potential to emigrate have considered doing so and the highly skilled - of all races - are most likely to be drawn abroad. These categories of people are forging relationships with international organisations, inviting them into the South African business scenario. Most countires in Africa, seeing South Africa as an economic hub in Southern Africa, do not expect its nationals to move out of the country.

There has been a limited response from the South African government in addressing the migration of skilled South Africans. Government support has been offered to the Homecoming Revolution, a non-profit organisation aimed at encouraging South Africans living abroad to return. The campaign consists largely of advertising and media-based efforts, with no formal structure in place, apart from a website, to promote and publicise South Africa. Efforts are being made to provide knowledge support (passport and visa queries, job opportunities and so forth) through the website (Lundy \& Visser 2003). However, the limited response to this issue may be in part because of the former president of South Africa, Thabo Mbeki, who stated that having more emigrants is an advantage when it comes to the adjustment of levels of employment opportunities.

The respondents of a South African quantitative research survey conducted by the researcher indicated that they maintain contact with their home country through a variety of means. Thirty-one per cent stayed abreast of events in South Africa through the media, 22\% had ongoing business contact with the country, 20\% maintained contact through academic exchanges and relationships and $7 \%$ used conferences and other professional activities to stay in touch. These data support the hypothesis that skilled South Africans living in the diaspora wish to remain in contact with their homeland. All overseas diaspora members who are South Africans, either by birth or through naturalisation, joined the diaspora network through their linkage with the South African Business Club (Magocha 2014).

South Africans have power and influence in their host countries. One-third of respondents stated that they had considerable or major influence over the investment decisions of their organisations. About $40 \%$ reported that their organisations were engaged in some international and developing market activities, with 35\% of organisations having business activities in South Africa. Fifty-four per cent of respondents reported that they had worked in organisations of 1000 people or less, while 13\% said to have worked in organisations with more than 1000 employees and had considerable influence over their company's investment decisions.

\section{Mobilising diaspora towards African change}

Mbeki's African renaissance initiatives and its call to all the peoples of Africa include those of the diaspora, 'to make their contribution to the regeneration of their mother continent' (Mbeki 2003 has echoes of Ghana's first President Kwame Nkrumah's exhortations to '[s]eek ye first the political kingdom, and all else shall be added onto you'). This momentum has been sustained by certain state leaders and intellectuals from across the continent and diaspora through a series of conferences under the auspices of the AU which have echoed Pan-Africanist rhetoric in 'the search for African rebirth or renaissance' (African Union 2006).

The African diaspora is already playing an important role in African development, remitting an estimated $\$ 45$ billion each year. The funds coming from the African diaspora overseas are financing African development projects of the countries of origin. This mobilises the diaspora to explore how these funds could be better structured to promote sustainable development on the continent. The transfer of intellectual resources and creative business practices by the African diaspora is also considered to be stimulating.

There are four broad areas for diasporas' engagement in development and change which are emergent in development practice. First and foremost are initiatives to improve and strengthen the flow of remittances. This includes working with the financial services industry to reduce the transaction costs for remittances and encourage migrants to send more funds through the formal banking system. Some have advocated for the provision of tax relief in industrialised states for remittances to developing countries and some developing countries have considered how to tax remittance income to raise funds for development (Ratha 2007:7).

As the potential contribution of diasporas to development is being recognised, there has been a general shift in attitude towards emigrants amongst the governments of many developing countries (Castles \& Delgado Wise 2008). Whilst some countries, such as Morocco, had little interest in those who had left, today they are 'courting the diaspora' (De Haas 2006) in a variety of ways.

Diaspora-based networks are a potential asset for individual business owners who exploit them in two primary ways: accessing resources unavailable or more expensive to acquire from other sources and providing a market for goods and services. Transnational diaspora-based linkages might enable access to different types of resources and/or markets. Utilisation of transnational diaspora-based networks may be seen as a transitional phase in the development of migrant businesses on the road to full assimilation into the host society, and therefore, a feature of newly arrived migrants' enterprises. 
Conversely, the maintenance and development of transnational networks might be a major, and permanent, contributor to minority business development and more likely therefore to be used by those who have established a secure foothold in the host country (Portes, Haller \& Guarnizo 2002).

\section{A major theory explaining the concept of diaspora in Africa}

Theories are crucial in shading light on what other scholars have highlighted in their researches concrning the issue under discussion. In this note, the socio-economic geographic unifying transnationalism theory formulated by Magocha (2014) explains how social, economic, geographic and unifying factors influence transnationalism. Robinson (1998) states that transnationalism refers to the diffusion and extension of social, political, and economic processes in between and beyond the sovereign jurisdictional boundaries of nation states. International processes are increasingly governed by non-state actors and international organisations.

\section{Socio-economic geographic unifying transnationalism theory}

Socio-economic geographic unifying transnationalism theoryis a combined theory that the research proposes for the promotion and support of migration dynamics and the making of diasporic business communities (Magocha 2014). The theory postulates that for business to be well established within the diaspora community, there is a need to consider social, economic, geographic, unifying and transnational issues. In fact, this theory argues that migration theories have to be combined in order for African migrants to effectively operate in business and form transnational businesses or companies. Migration theories concentrate on the push-pull factors; however, these are not sufficient to give a full explanation of migration dynamics and diasporic business processes, as they ignore the political facet of migration. Political relations also explain why people migrate to certain countries.

Socio-economic theories analyse the extent to which local government is responsible for ensuring the basic human rights or socio-economic rights spelt out in the South African Constitution of 1996, sections 26-29; local government also has a duty to foreigners who are legally in the country. More broadly, metros must be 'developmental', and developmental objectives are difficult to achieve amidst fragmented communities. According to the South African Local Government White Paper of 1998, municipalities must 'work with groups in the community to find sustainable ways to meet their social, economic, and material needs and improve the quality of their lives'. This means thinking beyond the narrow confines a set of delinked service sectors. One reason for this is that much of the research on Southern Africa's human immunodeficiency virus (HIV) and/or acquired immunodeficiency syndrome
(AIDS) epidemic has neglected important socio-economic, legal and cultural dynamics of migration that may be contributing to the spread of the virus. As Decosas and Adrien (1997) pointed out, the association between migration and HIV is more likely to be a result of 'the conditions and structure of the migration process than the actual dissemination of the virus along the corridors of migration' as currently assumed. We have also only just begun to realise that HIV itself is a cause of migration, as people move to access better healthcare or, as the macabre phrase suggests, 'return home to die'. These have negative effects on diasporic business communities, as people are demoralised by the HIV / AIDS levels of Southern Africa.

The other issue relating to migration lies in the fact that with an illegal alien population estimated to be between 2.5 million and 5 million in South Africa, it is obvious that the socio-economic resources of the country, which are under severe strain as it is, are further being burdened by the presence of illegal aliens. The cost implication of maintaining an illegal allien becomes even clearer when one makes a calculation, suggesting that if every illegal costs the South African infrastructure, say, R1000 per annum, then multiplied with whatever number you wish, it becomes obvious that the cost becomes billions of rands per year. This has ripple effects on the South African economy in terms of fiscal policies and the administration of social amenities.

On the other hand, if the immigrants become productive, they will have a positive effect on the gross national product and the gross domestic product, which will raise the status of the economy on global economic measures. Migration policies should be incorporated in a structured manner into policies on health, education and human capital, and into social and economic development strategies. Migration and development policies should also focus much more on economic reform and job creation and on improving the working conditions and the socio-economic situation in lowincome and middle-income countries, and in regions characterised by high emigration pressures. This would include promoting access to quality education for all, the development and improvement of vocational training and the reinforcement of management skills, and further developing the role of the formal labour markets.

The International Organization for Migration (IOM) (2003) asserts that a number of countries have various strategies in place to assist with the socio-economic integration of migrants, regardless of whether they are permanent. These include language training, translation services, information referral, migrant resource centres, access to healthcare, employment possibilities for spouses and the right of family members to accompany the migrant. This allows the immigrants to contribute to the development of the host country. Migration simultaneously reshapes the socio-economic 'development' context at both the origin and the destination, which in their turn are likely to 
influence subsequent migration patterns. For example, remittances sent back to family members could alter the social and economic context in the areas of origin and encourage subsequent migration (Van Dalen, Groenewold \& Fokkema 2005).

Levitt (1998) stresses the importance of 'social remittances', which she interprets as a local-level, migration-driven form of cultural diffusion. This flow back consisting of ideas, behaviours and identities not only plays an important role in potentially promoting immigrant entrepreneurship, family formation and political integration, but also affects the perceptions, feelings of relative deprivation and aspirations of people, which are also likely to affect subsequent migration patterns.

At the meso and micro level, migration was supposed to lead to the economic improvement of migrants and greater freedom from local socio-economic barriers and constraints. Remittances would 'improve income distribution and quality of life beyond what other available development approaches could deliver' (Keely \& Tran 1989:500). As it is already the better-off who tend to migrate, socio-economic inequalities within communities will increase because the remittances and other benefits of migration go disproportionally to the better-off (Lipton 1980). Therefore, migration will not contribute to the alleviation of the poverty of the worst-off. Instead, the gradual undermining of traditional economies may even increase the deprivation of non-migrants. In south European countries such as Spain, Italy and Greece, and East Asian countries such as Malaysia and South Korea, remittances have played a significant positive role in their successful - national economic development, and in reaction to sustained socio-economic development in their countries of origin, many international migrants have, in fact, invested significantly in private enterprises (De Haas 2008:33).

In many socio-economic settings, the household was recognised as the most relevant socio-economic group and hence the most appropriate unit of analysis, acknowledging that the forms of households vary across time, space and socio-economic groups (McDowell \& De Haan 1997:3). This reflects the idea that migration starts from the individual household, and then spreads to national levels. This theoretical construction is based on the proposition that migration is an evolutionary process that contributes to institutional and socio-economic change both at origin and destination through various feedback mechanisms. Examples of the latter include the redistribution of income of the households involved in migration, both in absolute and relative terms, as well as the redistribution of land and capital. These processes ultimately result in changes in the social hierarchy (Massey et al. 1993:451-454). As one of the consequences, because return migrants usually possess more human capital than the immobile population, the nonmigrant group increasingly aspires to a privileged position in the community.
South Africa and the SADC have committed to an ongoing process of greater regional integration. Although the regularisation of movement between South Africa and Zimbabwe is partly a response to the current socioeconomic crisis, it is also an opportunity to forge longer term relations between the countries towards regional integration. These endeavours have inspired friendly and positive socio-economic relationships between sister cities, and by proxy, within local and immigrant communities. Sister city relationships provide another example of the increasing importance of transnational networks in establishing multifaceted ties between two countries. As Karen Fog Olwig (2003:787) affirms, 'transnational theory has successfully highlighted the significance of migrants' attachments to people and places transcending the confines of nation-states'.

The AU has also committed to formally recognising the African diaspora as a sixth regional bloc alongside the economic communities of Southern, Central, West, East and Saharan regions of the continent. Within the AU's Economic, Social and Cultural Council (ECOSOCC), 20 of the 150 seats are reserved for diaspora organisations that represent the 'first institutional interface between the Union and its constituents in the diaspora' (Oladeinde 2006). These efforts to 'mainstream' the diaspora in the activities of the AU are also apparent in the plans of the AU Commission to launch Diaspora Forums in Europe and the Western Hemisphere, with the latter first convened during December 2002 (African Union 2003). A series of regional conferences and the first AU Diaspora Ministerial Conferences held in South Africa during November 2007, as well as an African Diaspora Summit in May 2008, have also highlighted the importance of this policy shift. Most recently, the AU has called for a 'paradigm shift in the way migration is managed' given its 'increased importance and untapped potential' as an 'engine for regional co-operation and integration as well as [the] socio-economic development of the Continent' (African Union 2006:4-6).

The New Partnership for Africa's Development (NEPAD) is a socio-economic development programme, and one of its main objectives is economic integration and interstate trade. The projects cited in the document drawn up by the African Development Bank, NEPAD Short-Term Action Plan: Infrastructure (NEPAD 2002), embody a vision to develop the continent. These include power systems, gas or oil transmissions, regional capacity-building, water and sanitation projects, the development of trade corridors, better and safer roads 'to bring Africa together', ports, railways and telecommunications (Reitzes 2004:343). All these projects require trans-border cooperation and collaboration, as all will require the cross-border movement of skills, capital, goods and labour. The recent socio-economic literature on the role of diasporas argues that trade, technology diffusion and capital formation are facilitated by migrants. The argument is that migrants facilitate host and source country bilateral trade and investment because they help to overcome 
information asymmetries and other market imperfections (Black, King \& Tiemoko 2003).

Through the exposure to migrants' (perceived) relative success, wealth and status symbols (international), migration has almost become an obsession, as it is perceived as the main or only avenue for upward socio-economic mobility (Epstein 2008), and in which ambitions, life projects and dreams of people are generally situated elsewhere. The fact that migrants often have a tendency to present themselves as successful and to conceal their economic and social problems would further fuel this culture of migration. In general, Massey (2002) perceives international migration in postindustrial countries as an outcome of socio-economic development and integration processes. Nonetheless, at the current stage of development, these ideas are far from constituting an all-inclusive theory of migration, and it would seem that their operationalisation in practical applications is unlikely. This idea supports world systems and transnationalism theory that holds that there has to be an open system which connects business activities across the regions or the world.

In countries like Zimbabwe and South Africa, migration dynamics and the making of diasporic business communities are exacerbated by the countries' geographic position, relative lack of capacity regarding border control and immigration services generally, current complex nationbuilding redefinition and, paradoxically, a historical legacy of absolute control of populations' movements. The distribution of immigrants amongst the different economic activities is conditioned by several factors: the sectoral composition of the economies, the immigrants' skills, the reservation wages of the foreign population compared to those of the native population and the behaviour of entrepreneurs. Orłowski (2000), in explaining emigration rates, adds the population size and unemployment rates of the destination region as well as geographic distance. Boeri and Brücker (2001) found a significant effect of such variables as employment rates, institutional restrictions on migration, presence of migrant networks, cultural (language) proximity as well as standard of living on the stocks of Central and Eastern European migrants residing in the 'old' EU-15 countries. Alecke, Huber and Untiedt (2001) used unemployment rates in both the sending and receiving countries, along with country-specific dummies, to model the origin-destination emigration rates.

Many geographic models, despite being based on stochastic processes (notably, Markov chains), and thus having large potential for simulation-based uncertainty assessment, do not, to date, seem to have been widely explored in this context. Moreover, the judgemental scenarios that often form the input to the models of population dynamics often assume the constancy of migratory flows starting from a given period of time. Although such an approach is understandable, given the lack of specific knowledge of the researcher about the more distant future, the constancy assumption seems to be the neutral option; it is also likely to generate very high ex- post forecast errors. Nevertheless, as international migration will most probably continue to be a dynamic process, this approach cannot be expected to produce reasonable results in the long term. A series of econometric models, including the so-called differences-in-differences estimations, were used to examine this question, while controlling for several standard determinants of foreign investment flows, such as country size, geographic distance and cultural similarities (Magocha 2014).

The story of the post-Second World War Chinese diaspora is one of geographic mobility and economic diversification: the construction of a 'bamboo network' linking Hong Kong (China), Indonesia, Malaysia, the Philippines, Singapore, Taiwan (China) and Thailand to one another and to China through meshed webs of family firms operating first in traditional trading and manufacturing, and then in high-tech and finance. For many refugees, the years following the Communist victory in 1949 were a time of testing, relieved some would say redeemed - by rags-to-riches stories. In the conventional telling, frugal, canny traders, often with nothing but the clothes on their back, worked their way up from factory floor to great wealth (Kuznetsov 2006:13-14). Soon, the overseas Chinese held key positions in real estate development, component manufacturing and construction, sectors that put a premium on the ability to combine trading and productive skills. At the same time, Taiwan (China) was developing a distinctive style of business organisation that fused elements of the traditional, small Chinese firm and the Silicon Valley start-up. With the start of Deng Xiaping's open door policy in 1978, China turned away from isolation and autarky and welcomed the successful overseas Chinese as investors. The influx from Hong Kong (China) and Taiwan (China) was particularly great because of proximity and historical ties. Multinational firms flocked to the mainland, partly to decentralise existing operations to a low-cost location, partly to participate in the widely anticipated growth of a huge market, and partly because partnering with key members of the Chinese diaspora was often regarded as indispensable to navigating an opaque political environment. Today, traditional lines of business are increasingly being abandoned in favour of the most modern sectors of the economy. Having helped transform China, the Chinese diaspora is now being transformed by the development it encouraged (Kuznetsov 2006).

The uneven and fractured class, racial, gender, generational, geographic, ethnic and even linguistic awareness which characterises these diasporas has fluctuated considerably over time, making it complicated to map not only their changing boundaries but also their changing connections with their countries of origin, as well as with the African continent itself. Indeed, any investigation of diaspora politics and activities must be sensitive to the fact that diasporas comprise an integral and distinctive part of the globalised political economy (Davies 2007). Secondly, such an investigation would need to incorporate mobility and transnational engagement as a fundamental aspect of 
peoples' lives. This means that it cannot be constrained within specific geographic boundaries. Clemens and Pritchett (2008) take this to its logical extreme by arguing that development should be assessed with reference to people rather than places. The spatial and geographic distribution of labour, as well as economic competition, resulted in the emergence of regional economic blocs in central and western Europe (the European Union); North America, Canada and Mexico; the Asian-Pacific rim; the Middle East; West Africa; East Africa; and parts of South America. Such regional focus is in keeping with the objectives of NEPAD and the impact of globalisation (Reitzes 2004). In the case of Mozambique, the geographic situation facilitates the crossing of borders as well as human trafficking, because South Africa is being targeted as the destination for migrants, and as the place for cross-border traders because of its links to the rest of the world through its well-established infrastructure (Raimundo 2009:97).

It has to be noted that the presented survey of migration theories is by no means complete, and that a much more comprehensive discussion is offered by Massey et al. (1993), Zlotnik (1998) and Jennissen (2004:31-57). For example, the distinction between theories explaining the initiation of international migration, and the ones related to the perpetuation of population movements introduced by Massey et al. (1993), is not considered in the current study. Such a division might be potentially useful if forecasters were to make an attempt to distinguish migration continuing under unchanging external circumstances from that related to system shocks (political or economic), the latter explained by the theories of initiation of population flows. Many theories attempting to explain population movements refer to internal migration. Nevertheless, they are included in the discussion because contemporarily, given the globalisation processes, the complexity of migratory phenomena increases, whilst the diversity between the mechanisms driving internal and international migration becomes less and less obvious. Unifying theories of migration are difficult to formulate; however, ways have to be found because one theory alone is not sufficient to explain the migration dynamics and diasporic business communities therein. Business has to be transnationalised, as shown in Figure 1.

Although transnationalism and globalisation overlap, global processes are typically 'decentred' from national territories and occur in a global space, whilst transnational processes are 'anchored in and transcend one or more nation-states' (Kearney 1995:548). Perhaps, the earliest example of migrant transnationalism is found in the concept of diaspora, which initially referred to the forcible dispersal of Jews from their original homeland (Cohen 1997:1-29). Ratha and Mohapatra (2011) assert that diaspora is conceived as a process of transition 'constituted as much in difference and division as it is in commonality and solidarity' in Anthias (1998:564). Diasporic communities are characterised by a profoundly different articulation of territory and belonging; these new

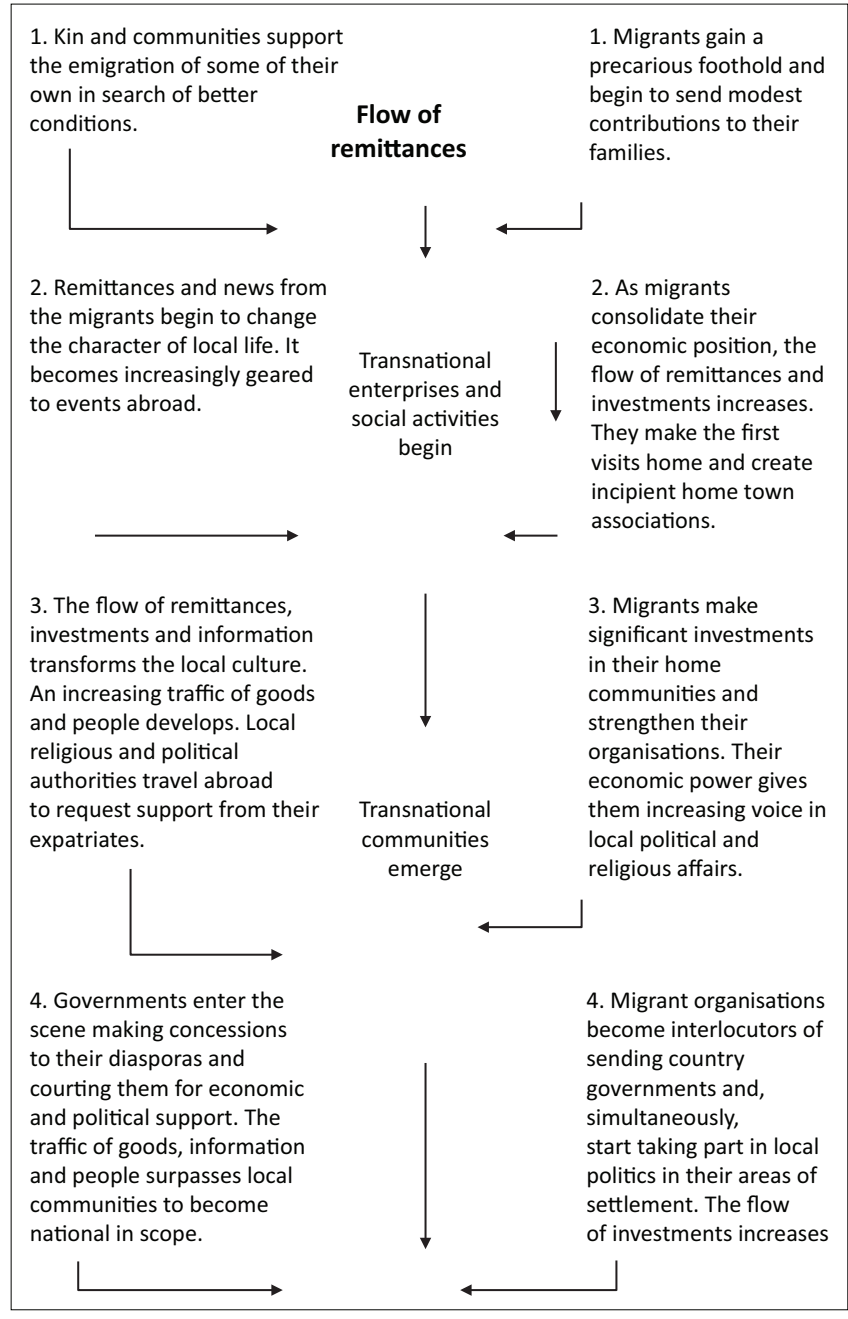

Source: Adapted from Portes, A., Escobar, C. \& Walton, A., 2006, 'Immigrant transnationa organizations and development: A comparative study', International Migration Review 41(1), 242-281. https://doi.org/10.1111/j.1747-7379.2007.00063.x

FIGURE 1: The process of immigrant transnationalism.

loyalties contain both transnational and sub-national links, as well as 'nonnational identities and aspirations'. Thus, 'diaspora' includes a comprehensive representation of 'community members who are dispersed to many diverse regions of the world, and who yet retain a myth of their uniqueness and an interest in their homeland' (Kearney 1995:559). Diasporas should be distinguished from other patterns of migration across time and space and are constituted by three core elements: dispersion across or within state borders; orientation to a 'homeland' as a source of value, identity and loyalty; and boundary maintenance, involving the preservation of a distinctive identity vis-à-vis a host society over an extended time period (Brubaker 2005:5). Much of the debate in the literature has treated the diaspora as a homogeneous grouping. Important questions about the depth and power of diasporicidentifications-external categorisation and self-understanding, objective commonality and subjective groupness (Brubaker \& Cooper 2000:27) - about the complex process by which class, gender and other alignments subvert and even supersede diasporic ideologies, as well as about the advent of 'new' and changing diasporic groups and identifications, are often absent from this scholarship. 
Similarly, it is contended that the relatively recent body of work concerned with the concepts of transnationalism and diaspora has not properly challenged traditional analytical categories. Set against the structural backdrop of the global political economy, it is evident that diasporic communities can be varied and complex both in their structure and character. Indeed, the available evidence suggests that a variety of fragmented and diverse links with homeland are maintained by the many disparate elements of Africa's expatriate populations and global diaspora (Akyeampong 2005; Zeleza 2005). Reis (2004:46) distinguishes between two groups of diaspora theorists. Firstly, there are those who focus on 'classical' diaspora based on the Jewish archetype; secondly, there are those who co-mingle contemporary diaspora with issues of transnationalism and globalisation.

\section{Conclusion}

From a conceptual perspective alone, the preceding discussion suggests that there is a real need to reposition the debate towards a conceptualisation of diaspora that is cognisant of the complexity of the phenomena in what has been termed the 'age of migration' (Castles \& Miller 2003). Perhaps, the earliest example of migrant transnationalism is found in the concept of diaspora, which initially referred to the forcible dispersal of Jews from their original homeland (Cohen 1997:1-29). Today diaspora is conceived as a process of transition 'constituted as much in difference and division as it is in commonality and solidarity' (Anthias 1998:564). Diasporic communities are characterised by a profoundly different articulation of territory and belonging, these new loyalties containing both transnational and sub-national links as well as 'nonnational identities and aspirations'.

Zimbabwe is one of Africa's great ancient civilisations, establishing itself as a major culture and region of trade as early as 3000 BC. The Zimbabweans were mainly of Bantu stock and practised cattle keeping and agriculture. In fact, Zimbabweans were probably known by the ancient Egyptians and the Chinese. Buildings in Zimbabwe, especially the stone cities covering an area of the size of France, seem to have been built hundreds of years before Christ to as recently as the 10th century AD. By about 500 BC, the Zimbabweans were engaged in trade with parts of Asia and Yemen. As early as 1000 BC, black people called Lemvo who were of the Jewish faith migrated to Zimbabwe from the Ethiopian Empire. Zimbabwe was also one of the world's greatest producers of rice, cloth, iron utensils and gold adornments. Zimbabwe's renaissance may have taken place from as early as $300 \mathrm{BC}$ and continued to about $1200 \mathrm{AD}$. Whist much of Zimbabwe's great art, its gold work and its great buildings have been plundered or almost destroyed, the ancient buildings built in Zimbabwe are so widespread and so huge that most still exist.
The Great West African renaissances, which took place between 400 BC and 1600 AD, involved three of the world's greatest and wealthiest kingdoms and empires: Ghana (400 BC-1200 AD), Mali (1200-1500 AD) and Songhai (1500-1700 $\mathrm{AD})$. From the above discussion, one may justifiably say that migration and renaissance are the double-edged catalysts of humanity's evolutionary continuum. The diaspora and the renaissance function is crucial in the development of the global world. Diaspora in Afrikological contexts and the resultant renaissance are the key to African prosperity. Therefore, African diaspora and the government systems should support the movement of people and resources. Diaspora gave rise to South African renaissance in the 21st century. It is the plight of this article that African governments should mobilise diaspora towards African change. The major theory explaining the concept of diaspora in Africa is known as socio-economic geographic unifying transnationalism theory. Socio-economic geographic unifying transnatioalism theory came with elements of social development, economic development and geographic development that were all meant to unify the world and coming up with transnational concepts of renaissance of the African economies leading to the formation of United States of Africa.

\section{Acknowledgements Competing interests}

The authors have declared that no competing interest exists.

\section{Author's contributions}

I declare that I am the sole author of this research article.

\section{Ethical consideration}

This article followed all ethical standards for a research without direct contact with human or animal subjects.

\section{Funding information}

This research received no specific grant from any funding agency in the public, commercial or not-for-profit sectors.

\section{Data availability statement}

The data that support the findings of this study are available from the corresponding author, M.M., upon reasonable request.

\section{Disclaimer}

The views and opinions expressed in this article are those of the author and do not necessarily reflect the official policy or position of any affiliated agency of the author.

\section{References}

African Union, 2003, The development of the diaspora initiative within the framework of the OAU/AU, Executive Council, Third Extraordinary Session, Sun City.

African Union, 2006, The migration policy framework for Africa, Executive Council, Ninth Ordinary Session, Banjul, The Gambia, 25-29 June. 
Akyeampong, E., 2000, 'Africans in the diaspora: The diaspora and Africa', African Affairs 99(395), 183-215. https://doi.org/10.1093/afraf/99.395.183

Akyeampong, E., 2005, 'Diaspora and drug trafficking in West Africa: A case study of Ghana', African Affairs 104(416), 429-447. https://doi.org/10.1093/afraf/adi015

Alecke, B., Huber, P. \& Untiedt, G., 2001, 'What difference a constant makes? How predictable are international migration flows?', in Migration policies and EU enlargement. The case of Central and Eastern Europe, pp. 63-78, Organisation for Economic Co-operation and Development (OECD), Paris.

Anthias, F.,1998, 'Evaluating diaspora: Beyond ethnicity?', Sociology 32(3), 557-580. https://doi.org/10.1017/S0038038598000091

Barton, P.A., 2001, A history of the African-olmecs black civilizations of America from prehistoric times to the present era, Author House, Bloomington, IN.

Beach, D.N., 1994, A Zimbabwean past: Shona dynastic histories and oral traditions, Mambo Press, Gweru.

Black, R., King, R. \& Tiemoko, R., 2003, Migration, return and small enterprise development in Ghana: A route out of poverty? Sussex Migration Working Paper no. 9, Sussex Centre for Migration Research, University of Sussex, Brighton.

Blakewell, O., 2010, In search of the diasporas within Africa, International Migration Institute, University of Oxford, viewed 11 January 2012, from http://www.imi. ox.ac.uk/about-us/people/oliver-bakewell/.

Boeri, T. \& Brücker, H., 2001, Eastern enlargement and EU labour markets: Perceptions, challenges and opportunities, IZA Discussion Paper 256, Institut zur Zukunft derArbeit, Bonn.

Brubaker, R., 2005, 'The "diaspora" diaspora', Ethnic and Racial Studies 28(1), 1-19. https://doi.org/10.1080/0141987042000289997

Brubaker, R. \& Cooper, F., 2000, 'Beyond identity', Theory and Society 29(1), 1-47. https://doi.org/10.1023/A:1007068714468

Campagnon, D., 2011, A predictable tragedy: Robert Mugabe and the collapse of Zimbabwe, University of Pennsylvania Press, Philadelphia, PA.

Castles, S., 2010, 'Will labour migration lead to a multicultural society in Korea?', paper presented at the Global Human Resources Forum, Seoul, Korea, October 2007.

Castles, S. \& Delgado Wise, R. (eds.), 2008, Migration and development: Perspectives from the South, International Organisation for Migration, Geneva.

Castles, S. \& Miller, M., 2003, The age of migration, Palgrave Macmillan, Basingstoke.

Choi, C.Q., 2014, Live science contributor: Ancient Arabian stones hint at how human migrated out of Africa, viewed 01 January 2015, from http://www.livescience. com/47555-stone-artifacts-human-migration.html.

Clemens, M.A. \& Pritchett, L., 2008, 'Income per natural: Measuring development for people rather than places', Population and Development Review 34(3), 395-434. https://doi.org/10.1111/j.1728-4457.2008.00230.x

Cohen, R., 1997, Global diasporas: An introduction, University College Press, London.

Crush, J., 2000, 'The dark side of democracy: Immigration, xenophobia and human rights in South Africa', International Migration 38(6), 103-131. https://doi.org/ 10.1111/1468-2435.00145

Davies, R., 2007, 'Reconceptualising the migration-development nexus: Diasporas, globalisation and the politics of exclusion', Third World Quarterly 28(1), 59-76. globalisation and the politics of exclusion',
https://doi.org/10.1080/01436590601081823

De Haas, H., 2006, Engaging diasporas: How governments and development agencies can support diaspora involvement in the development of origin countries, Oxfam Novib, The Hague.

De Haas, H., 2008, Migration and development: A theoretical perspective, Internationa Migration Institute, University of Oxford, Oxford.

Decosas, J. \& Adrien, A., 1997, 'Migration and AIDS', AIDS 11(Suppl. A), S77-S84.

Ellerman, D., 2003, Policy research on migration and development, Policy Research Working Paper 3117, World Bank, Washington, DC

Epstein, G.S., 2008, 'Herd and network effects in migration decision-making', Journa of Ethnic and Migration Studies 34(1), 567-583. https://doi.org/10.1080/ 13691830801961597

Grenville, J.A.S., 1997, A history of the world in the twentieth century, vol 1, Bellknap Press, Cambridge, MA

Hammar, A., McGregor, J. \& Landau, L., 2010, 'Introduction. Displacing Zimbabwe: Crisis and construction in Southern Africa', Journal of Southern African Studies Crisis and construction in Southern Africa', Journal of Southern
36(2), 263-283. https://doi.org/10.1080/03057070.2010.485779

International Organization for Migration (IOM), 2003, International terrorism and migration, Migration Policy and Research Department, IOM, Geneva.

Iroegbu, P., 2010, Migration and diaspora: Craze, significance and challenges, Holler Africa, viewed 30 Janury 2012, from http://www.hollerafrica.com/showArticle. php?\%20artld $=121 \&$ catld $=\% 201$ \&page $=1$.

Jefferson, T., 1944, 'Notes on Virginia', in A. Koch \& W. Paden (eds.), The life and selected writings of Jefferson, Penguin Classics, New York, NY.

Jennissen, R., 2004, Macro-economic determinants of international migration in Europe, Dutch University Press, Amsterdam.

Kearney, M., 1995, 'The local and the global: The anthropology of globalisation and transnationalism', Annual Review of Anthropology 24, 547-565. https://doi.org/ 10.1146/annurev.an.24.100195.002555

Keely, C. \& Tran, B.N., 1989, 'Remittances from labor migration: Evaluations, performance, and implications', International Migration Review 23, 500-525. https://doi.org/10.1177/019791838902300306

Kuznetsov, Y., 2006, Diaspora networks and the international migration of skills: How countries can draw on their talent abroad, World Bank Institute of Development Studies, Washington, DC.
Levitt, P., 1998, 'Social remittances: Migration driven local-level forms of cultural diffusion', International Migration Review 32(4), 926-948. https://doi.org/ 10.1177/019791839803200404

Levitt, P., 2001, The transnational villagers, University of California Press, Berkeley, CA.

Levitt, P., 2010, Transnational migrants: When 'home' means more than one country, Migration Information Source, Migration Policy Institute, viewed from 29 January 2012, from http://www.migrationinformation.org/Feature/display.cfm?ID=261.

Lewis, R., 2005, 'Insider movements: Retaining identity and preserving community', in R.D. Winter \& S.C. Hawthorne (eds.), Perspectives on the world Christian
movement: A reader, 4th edn., pp. 673-675, William Carey Library Publishers, movement: $A$
Pasadena, CA.

Lipton, M., 1980, 'Migration from the rural areas of poor countries: The impact on rural productivity and income distribution', World Development 8(1), 1-24. https://doi.org/10.1016/0305-750X(80)90047-9

Lundy, G. \& Visser, W., 2003, South Africa: Reasons to believe!, Aardvark Press, Cape Town.

Magocha, M., 2014, 'The role of Zimbabwean diasporic SMMEs in the South African Economy', unpublished thesis, University of South Africa, Pretoria.

Makgoba, M.W. (ed.), 1999, African renaissance, Mafube-Tafelberg, Cape Town.

Makina, D., 2009, The impact of regional migration and remittances on development, viewed 01 Febrauary 2011, from http://www.idasa.org.za.

Massey, D.S., 2002, 'A synthetic theory of international migration', in V. Iontsev (ed.), World in the mirror of international migration, pp. 142-152, MAX Press, Moscow.

Massey, D.S., Arango, J., Hugo, G., Kouaouci, A., Pellegrino, A. \& Taylor, E., 1993 'Theories of international migration: A review and appraisal', Population and Development Review 19(3), 431-466. https://doi.org/10.2307/2938462

Mbeki, M., 1999, The African renaissance. South African yearbook of international affairs, 1998/9, South African Institute of International Affairs, Johannesburg.

Mbeki, T., 1998, Africa - The time has come, Mafube-Tafelberg, Cape Town.

Mbeki, T., 2003, 'Mbeki claims millions of Zimbabweans in SA', News24, 16 September.

McDonald, D., Gay, J., Zinyama, L., Mattes, R. \& De Vletter, F., 1998, Challenging xenophobia: Myths and realities about cross-border migration in Southern Africa, Migration Policy Series No. 14, Southern African Migration Project, Cape Town.

McDowell, C. \& De Haan, A., 1997, Migration and sustainable livelihoods: A critical review of the literature, Institute of Development Studies, Sussex.

Mohamoud, A.A., 2003, Institutional and capacity enhancement: An African perspective, Report for the Netherlands Ministry of Foreign Affairs, Sub-Sahara Department, Amsterdam, SAHAN.

Mohamoud, A.A., 2008, Engaging African diaspora in Europe as strategic agents for development in Africa: Seminar Report, African Diaspora Policy Centre, Brussels.

Mohan, G. \& Zack-Williams, A.B., 2002, 'Globalisation from below: Conceptualising the role of the African diaspora in Africa's development', Review of African Political Economy 29(92), 211-236. https://doi.org/10.1080/03056240208704610

New Partnership for Africa's Development (NEPAD), 2002, Executive Summary [Draft] Short-Term Action Plan Infrastructure, African Development Bank, Centurion.

Oladeinde, F., 2006, 'Remarks by the President of the Foundation for Democracy in Africa' in Regional Consultative Meeting on the Economic Social and Cultural Council (ECOSOCC) of the African Union at the Africa Leadership Forum, Ota, Nigeria, 15 June.

Olwig, K.F., 2003, “"Transnational” socio-cultural systems and ethnographic research: Views from an extended field site', International Migration Review 37(3), 787-811. https://doi.org/10.1111/j.1747-7379.2003.tb00158.x

Orłowski, W., 2000, 'Migration from central and eastern European countries after the accession: Effects for regions, labour markets, and social security systems', Research Bulletin 2(9), 7-21.

Portes, A., Escobar, C. \& Walton, A., 2006, 'Immigrant transnational organizations and development: A comparative study', International Migration Review 41(1), 242-281. https://doi.org/10.1111/j.1747-7379.2007.00063.x

Portes, A., Haller, W. \& Guarnizo, L., 2002, 'Transnational entrepreneurs: An alternative form of immigrant economic adaptation', American Sociological Review 67(2), 278-298. https://doi.org/10.2307/3088896

Raimundo, I.M., 2009, 'International migration management and development in Mozambique: What strategies?', International Migration 47(3), 93-122. https:// doi.org/10.1111/j.1468-2435.2009.00525.x

Ratha, D., 2007, Leveraging remittances for development, MPI Policy Brief, Migration Policy Institute, Washington, DC.

Ratha, D. \& Mohapatra, S., 2011, Preliminary estimates of diaspora savings, Migration and Development Brief 14, World Bank, Washington, DC.

Reis, M., 2004, 'Theorising diaspora: Perspectives on "classical" and "contemporary" diaspora', International Migration 42(2), 41-56. https://doi.org/10.1111/j.00207985.2004.00280.x

Reitzes, M., 2004, 'NEPAD and neighbours: An international exploration of principles to inform African labour migration regimes', Journal of Contemporary African Studies 22(3), 343-366. https://doi.org/10.1080/0258900042000283502

Robinson, W.I., 1998, 'Beyond nation-state paradigms: Globalization, sociology, and the challenge of transnational studies', Sociological Forum 13(4), 561-594. https://doi.org/10.1023/A:1022806016167

Tannenbaum, F., 1946, Slave and citizen: The Ne ro in the Americas, Vintage Books, New York, NY.

The White Paper on Local Government, 1998, Local Government. South Africa, Government Printers, Pretoria. 
United Nations Population Division, 2002, International Migration Report, United Nations, New York, NY.

Van Dalen, H.P., Groenewold, G. \& Fokkema, T., 2005, 'The effect of remittances on emigrationintentions in Egypt, Morocco, and Turkey', Population Studies A Journal of Demography 59, 375-392. https://doi.org/10.1080/ 00324720500249448

Wan, E. \& Tira, S.J., 2008, 'Diaspora missiology', in S.J. Tira \& E. Wan (eds.), Missions in action in the 21st century, p. 44, Prinbridge, Toronto.

Wettstein, H., 2002, 'Coming to terms with exile', in H. Wettstein (ed.), Diasporas and exiles: Varieties of Jewish identity, pp. 47-59, University of California Press, Berkeley, CA.
World Bank, 2005, 2005 PRS Review: Balancing accountabilities and scaling up results, viewed 15 March 2011, from http://siteresources.worldbank.org/INTPRS1/ Resources/PRSPReview/2005 Review_Final.pdf.

Zaretsky, T., 2006, 'A missiological study of Jewish Diaspora', Paper presented at the Global Diaspora Consultation, Taylor University College, Edmonton, Alberta, Canada, 15-18 November, p. 4.

Zeleza, P.T., 2005, 'Rewriting the African diaspora: Beyond the black Atlantic', African Affairs104(414), 35-68.

Zlotnik, H., 1998, 'The theories of international migration', paper presented at the Conference on international migration: Challenges for European populations, Bari, Italy, June 25-27,1998, n.p. 